Article

\title{
Crisis Capitalism and Climate Finance: The Framing, Monetizing, and Orchestration of Resilience-Amidst-Crisis
}

\author{
Joshua Long \\ Environmental Studies Program, Southwestern University, Georgetown, TX 78626, USA; E-Mail: jlong@southwestern.edu
}

Submitted: 11 October 2020 | Accepted: 8 February 2021 | Published: 28 April 2021

\begin{abstract}
Throughout the development sector there has been a pronounced call for new funding mechanisms to address the climate crisis, and much of this is focused on attracting private sources of capital to fund 'bankable' projects in climate-vulnerable cities throughout the world. Enacted amidst a 21st century landscape of interlocking financial, epidemiological, and ecological crises, this call features an urgent narrative of 'resilience-amidst-crisis' that promotes large-scale, profitable investments as a form of green growth through debt-financing. The political orchestration and administration of new funding mechanisms (particularly green bonds and sustainable bonds) requires a new form of climate governance focused on the channeling of enormous sums of private capital through an assemblage of intermediaries toward profitable climate projects. This article interrogates this trend in climate finance, revealing that the framing, monetization, and orchestration of climate projects is dependent on a narrative of crisis capitalism deeply rooted in a colonial mindset of exploitation and profit. A key aim of this article is to deconstruct the contemporary dominance of crisis-oriented development and suggest the goal of decolonizing and democratizing the climate finance system.
\end{abstract}

\section{Keywords}

climate finance; climate governance; climate urbanism; crisis capitalism; resilience

\section{Issue}

This article is part of the issue "Is There a New Climate Politics? Emergency, Engagement and Justice" edited by Anna R. Davies (Trinity College Dublin, Ireland), Stephan Hügel (Trinity College Dublin, Ireland) and Vanesa Castán Broto (University of Sheffield, UK).

(C) 2021 by the author; licensee Cogitatio (Lisbon, Portugal). This article is licensed under a Creative Commons Attribution 4.0 International License (CC BY).

\section{Introduction}

Cities in the 21st century are attempting a multi-pronged response to climate change in an uncertain landscape of interlocking crises. While urban policymakers contend with the immediacy of climate hazards, most are also grappling with global economic recession, a looming global debt crisis, a widespread-but regionally differentiated-housing crisis, a persistent global pandemic, and a wave of social unrest and political volatility that stems from a range of structural issues (e.g., systemic racism, rising nationalism, increased authoritarianism, mismanagement, etc.). Indeed, 2020 may have been the year that the rhetoric of crisis became fully normalized in policy narratives, and this phenomenon has potentially worrisome consequences for equity and justice.
While narratives of crisis are employed at various scales of politics and governance, this article addresses the recent mainstreaming of crisis in the governance of climate finance at the municipal scale. Cities are presently targeted as the practical loci for climate mitigation and adaptation, and as such, have been highlighted as important recipients for climate funding. This has particular consequences for poorer cities of the global South, many of which are struggling to gain access to the funding and expertise needed to address overwhelming infrastructure deficits. That assistance is crucial, because the cost of climate-oriented development-particularly adaptation infrastructure-is enormous. Some projections have suggested that investment in climate action could be one of the largest ever mobilizations of investment capital, and one of the most profitable (New Climate Economy, 2018). 
The confluence of these factors has produced a precarious situation for some of the more vulnerable recipients of climate finance. As multilateral agencies and development organizations court a purportedly necessary partnership with private financial institutions of the global North, they have become focused on risk-averse and profitable (or 'bankable') climate-related projects. This partnership may be attractive to private investment, but it requires intermediaries and recipients to navigate an increasingly complex system of climate finance that lacks oversight, accountability, and efficiency. In short, while the more influential actors in this system push for urgent action in the face of crisis, recipients are increasingly forced into a potentially damning cycle of catastrophe, debt financing, and response.

This article interrogates some of the potential vulnerabilities and injustices in the contemporary landscape of climate finance. Ultimately, I argue that the framing, monetization, and orchestration of crisis has become a pervasive feature of climate governance and finance since the global financial crisis of 2007-2009. Within the past decade, the network of actors and intermediaries involved in the governance of climate finance has grown exponentially. At the same time, despite this diversity of new actors, a narrative of climate action has become increasingly mainstreamed. That narrative is largely an export of the global North, and represents a 'resilienceamidst-crisis' approach that is structurally embedded within a colonial mindset (Quijano, 2000).

Following a brief discussion of methodology and scale, this article introduces the relevant scholarship on crisis capitalism and its relationship with climate finance, emphasizing the ways that a neoliberal and colonial rhetoric of resilience is used to normalize an ongoing state of crisis and response. I then outline the ways in which the governance of climate finance has evolved since the global financial crisis. This includes a section on the framing of the climate crisis as an urgent and expensive challenge that requires private sector leadership. The next section summarizes the new financial mechanisms and strategies that have been created to engage private capital. The following section then briefly discusses the actors involved in the orchestration of those mechanisms and strategies. The article ends with a critique of this system, along with suggestions for strategies to decolonize and democratize climate-oriented development.

\section{Scale and Methodological Approach}

Critiquing climate finance and the climate development sector introduces challenges of scale and methodology that must be acknowledged. First, examining the role of climate finance in urban development necessitates a much broader examination of climate governance. Cities are not isolated actors in climate development. Funding major climate-oriented projects requires municipalities to seek out investment capital, forcing cities into relationships with institutions and actors at multiple scales, including multilateral agencies, state governments, regional non-government organizations, and a host of intermediary actors. This is true of most cities but particularly so of poorer cities who may lack the credit rating or technical expertise needed to secure and administer funding. Additionally, actions taken within cities have a significant impact on surrounding communities and regions, further complicating issues of scale. As a result, while this article is largely focused on urban projects and policies, it acknowledges the scalar reach of its arguments, suggesting that such a lens is necessary to critique the scope and complexity of climate finance.

Second, it is likely helpful to clarify what I mean by 'climate finance.' For the purpose of this article, I use the definition of climate finance introduced by the Climate Policy Initiative (Falconer \& Stadelmann, 2014, p. 4): "'Climate finance' typically refers to the financial resources paid to cover the costs of transitioning to a low-carbon global economy and to adapt to, or build resilience against, current and future climate change impacts." This is a broad definition. I use it intentionally because it captures the range of funding mechanisms that have been referred to as 'climate finance' in the development sector. Even though attempts at setting definitions and parameters exist (see, for instance, Brown, Bird, \& Schalatek, 2010), the ways in which climate finance has been distributed constitutes a vast spectrum of arrangements (Donner, Kandlikar, \& Webber, 2016; Hall, 2017; Roberts \& Weikmans, 2017). Indeed, ambiguity, complexity, and lack of accountability in the administration of climate finance is a primary justification for this research.

Lastly, in terms of methodology, I rely upon a range of disciplinary perspectives and primary sources of information to evidence my arguments. In Section 3, I draw from formative theoretical works on crisis and disaster capitalism, the climate crisis, and critical works on the rhetoric of resilience. For Sections 4 and 5, I reviewed 112 peer-reviewed scholarly works on green bonds, climate finance, and regionally-specific case studies of urban climate-oriented development from the fields of geography, economics, international policy, environmental studies, sociology, and international development. I located relevant case studies and peer-reviewed analyses published between 2009 and 2021 in the following databases: EBSCO, JSTOR, and Google Scholar. Of those, approximately 70 representative works were cited. Additionally, I conducted a discourse analysis of reports and promotional materials from approximately 40 major multilateral institutions, development agencies, investment banks, private consulting firms, interurban networks, and related organizations to identify and compare the parallels in the rhetoric they employed (see Table 1). The resulting analysis reveals a public campaign amongst development agencies and organizations at multiple scales to expand neoliberal ideals, engage 
Table 1. Primary sources (documents and reports) drawn from these organizations.

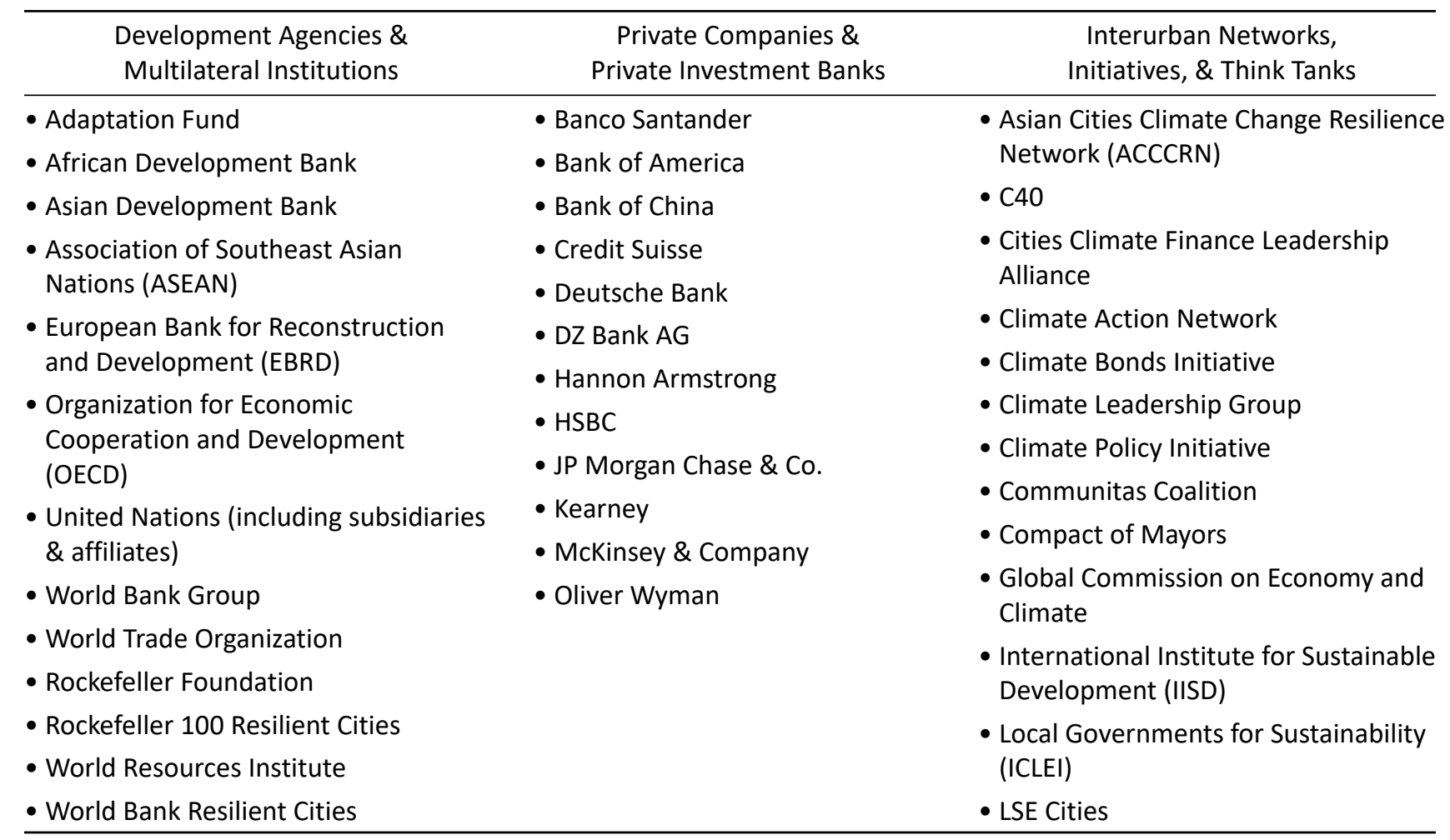

influential private capital, and employ strategic financial mechanisms in response to crisis-a phenomenon that scholars of crisis capitalism have been concerned with for more than a decade.

\section{Background: Questioning Crisis and Resilience in the Era of Climate Change}

Narratives of crisis have received a great deal of attention in the 21st century, although not always in name. In a very real sense, the scholarship on disaster capitalism and the rhetoric of resilience is also the scholarship of the framing and management of crisis. Combining these perspectives reveals a dual narrative of crisis and resilience that facilitates a cycle of creative destruction, investment, and response. This section briefly reviews some of the scholarship that highlights the coloniality of crisis capitalism and climate finance.

More than a decade ago, Klein (2007) introduced the concept of 'disaster capitalism' to describe the ability of powerful state actors and multilateral agencies to harness crises as opportunities for the expansion of neoliberal ideals and specific financial mechanisms. This framing of crisis matches Schuller and Maldonado's (2016, p. 62) definition of 'disaster capitalism' as "national and transnational governmental institutions' instrumental use of catastrophe...to promote and empower a range of private, neoliberal capitalist interests." There is a long history of framing disaster or crisis as a rhetorical antecedent to exploitative policies, but by the end of the first decade of the 21st century, it had become remark- ably commonplace in policy discourse (Castree, 2010). Indeed, responses to the September 11th terror attacks, to the increasing severity and prevalence of ecological disasters, and to financial crises have all been framed as crises in need of reactive policy measures; in each case the prescriptions involved the support and securitization or advancement of specific, influential capitalist interests (Boin, Hart, \& McConnell, 2009; Coaffee, 2009; Fletcher, 2012; Octavianti \& Charles, 2018; Pyles, Svistova, \& Ahn, 2017).

While the terms 'disaster capitalism' and 'crisis capitalism' have been used interchangeably (see for instance, Octavianti \& Charles, 2018), in this article, I refer to 'crisis capitalism' because it goes beyond implications of an event (a singular disaster or catastrophe) to more accurately refer to a systematic, ongoing condition of instability, danger, and vulnerability. As Azmanova (2020, p. 604) notes, since the financial collapse of 2007-2009, we find ourselves stuck in a protracted state of crisis: "Strategies for coping with the financial crisis have not solved the larger social crisis; short-term crisis management has become a new normal-we are stuck in perpetual crisis management." In the era of neoliberalism, this state of perpetual crisis management has facilitated new technocratic modes of development, new spheres of investment, and new networks for the administration of capitalist intervention (Harvey, 2010). Whether it be the global financial crisis, the climate crisis, Covid-19, or another crisis, these challenges are framed as persistent challenges that require market-based, capitalist interventions with the aim of achieving resilience. 
Resilience is a concept taken from ecology, where it is used to describe the ability of an ecosystem to 'bounce back' from shocks and stresses. In climate development circles, resilience has been used broadly to describe the ability of urban ecosystems, infrastructures, and entire communities to respond to and recover from climate hazards (Meerow \& Stults, 2016). In many ways, resilience has become a useful counter-discourse of crisis. The United Nations Intergovernmental Panel on Climate Change notes that, in response to the climate crisis, we must take steps to ensure a sustainable and resilient future. They define resilience as:

The ability of a system and its component parts to anticipate, absorb, accommodate, or recover from the effects of a hazardous event in a timely and efficient manner, including through ensuring the preservation, restoration, or improvement of its essential basic structures and functions. (Intergovernmental Panel on Climate Change, 2012, p. 3)

Some scholars have noted that, over the past decade, resilience has become a 'global urban policy project' widely adopted by international organizations, think tanks, and practitioners throughout the climate development sector (Webber, Leitner, \& Sheppard, 2020, p. 1). Its malleability has allowed various actors to appropriate it as an organizing principle, a developmental road map with flexible measures of assessment, and most importantly for this article: a useful vocabulary to frame neoliberal strategies of risk management (Bigger \& Webber, 2020; Webber et al., 2020). And while the basic concept of resilience is by no means fundamentally problematic, its appropriation and employment in climate finance is worrisome, as it normalizes the climate crisis as a mode of creative destruction in need of perpetual innovations, investment, and rebuilding.

Whether employed reactively in the wake of a disaster or strategically in climate adaptation initiatives, discourses of resilience are employed as a means to promote new development initiatives that are largely top-down, technocratic, and costly. Furthermore, they consistently overlook histories of colonial exploitation and structural injustice, thereby exacerbating, rather than alleviating, disparities and vulnerabilities (Evans \& Reid, 2014; McDonnell, 2020). As Ranganathan and Bratman (2019, p. 2) note, contemporary market-driven and technocratic visions of resilience "privilege design solutions and externally imposed ideas for community cohesion, while eliding the structural inequalities that make particular groups vulnerable to climate threats in the first place." Moreover, current policy discourses that employ the narrative of resilience-amidst-crisis are deeply embedded in colonial knowledge, supremacy, and violence (Reid, 2019; Serrano-García, 2020; Whyte, in press).

The resilience-amidst-crisis narrative referenced throughout this article is key to understanding the ways that climate finance represents a mechanism of colonialist interventionism. By resilience-amidst-crisis, I am referring to a three-part narrative that portrays a crisis as unprecedented and urgent, casts crisis victims as resilient subjects, and frames solutions in terms of access to capital markets, credit, and technocratic expertise. This narrative serves a dual function. The framing of crisis as unprecedented and urgent justifies policies that react to the present causes of the situation, thereby allowing the historical and structural causes of crisis to be obfuscated (Whyte, in press). At the same time, employing a resilience-amidst-crisis discourse romanticizes the survival capacity of disaster victims and fetishizes the resiliency of marginalized communities, thereby facilitating a disconnect that makes it easier to rationalize austere modes of governance and debt-bondage (Bigger \& Webber, 2020; Perry, 2020; Serrano-García, 2020).

Crisis capitalism relies on the exercise of creating resilient, but compliant, subjects who become dependent on a system of debt finance disguised as sustainable development. Evans and Reid (2014, p. 8) note the "enthusiasm" with which ideologues of sustainable development impose the language of resilience, ultimately suggesting that the "making of resilient subjects and societies fit for neoliberalism by agencies is based upon a degradation of the political capacities of human beings." Framing resilient development as an imperative that must be executed quickly to save vulnerable communities-while simultaneously restricting their political agency and trapping them in a system of debt bondage-firmly situates crisis capitalism within a colonial mindset of exploitation and supremacy.

It should be noted that crisis capitalism and its employment of a resilience-amidst-crisis narrative should be considered within the broader context of the neoliberalization of nature that occurred in response to the simultaneous challenges of climate crisis and economic crisis (see for instance Bumpus \& Liverman, 2011; Castree, 2010; Fletcher, 2012; While, Jonas, \& Gibbs, 2010, etc.). It also should be considered in light of works that consider the financialization of everyday life (see, for instance, Karaagac, 2020). This body of literature serves as a useful foundation for understanding the financialization and governance of the climate crisis. Their speculations about newly created carbon markets (Fletcher, 2012), carbon offsets and trading schemes (Bumpus \& Liverman, 2011), and carbon control and governance (While et al., 2010) remain highly relevant, but their discussion of crisis and power is most useful for this article.

These scholars and others focus on a trend that was just emerging at the time of their writing. That is, addressing the climate crisis introduces an extremely profitable frontier for financialization, investment, and influence. That frontier thrives on capitalism's ability to exploit the crises that it creates while also extracting value from vulnerable ecosystems, institutions, and people. Before addressing this further, it is necessary to 
provide a brief overview of the ways that systems of climate governance and finance have merged through the framing, monetization, and orchestration of crisis. The following section argues that a resilience-amidstcrisis narrative has been recently focused at the municipal scale. In short, the city and its citizens are then cast as resilient subjects whose response to the climate crisis is dependent on significant streams of investment and technocratic expertise to be channeled toward climateoriented infrastructure and development.

\section{Framing and Monetizing Crisis: Urgent, Urban, and Investable}

Throughout the past decade of compounding crises, multilateral agencies have mainstreamed a useful narrative of climate action. That message focuses on expanding markets to poorer regions through debt-finance mechanisms (Soederberg, 2013) and facilitating the role of private interests (through both philanthropic donors and private firms) in the governance of climate-oriented development (Graham, 2017; Seitz \& Martens, 2017). This occurred alongside an increased focus on cities as the preferred sites of financial investment and climate action-a strategy that gained recognition in academic, institutional, and government literatures (Angelo \& Wachsmuth, 2020; Rosenzweig, Solecki, Hammer, \& Mehrotra, 2010). As Angelo and Wachsmuth (2020) note, climate change has provided the context for the global institutionalization of urban sustainability and climate action, with multilateral organizations, philanthropic foundations, and development agencies focusing much of their attention on cities as the most effective scale of intervention. This began in earnest in the decade following the financial crisis, with examples like the World Bank publishing its Cities and Climate Change: An Urgent Agenda, United Nations Habitat beginning its Cities and Climate Change Initiative, the OECD publishing various analyses on Cities and Climate Change, and a host of new initiatives mainstreaming a narrative that championed the relative flexibility and speed at which cities can address climate change.

Several scholars have suggested this shift constitutes a new mode of urban development known as 'climate urbanism' (Castán Broto, Robin, \& While, 2020; Long \& Rice, 2019). As Robin and Castán Broto (2020) note, climate urbanism as a strategy for climate action is not a homogenous approach: It remains a contested concept. This article first critiques the dominant narrative of climate urbanism before discussing diverse and subaltern approaches that contest that narrative. That dominant narrative prioritizes carbon control, climate resilient infrastructure, and technological fixes in order to safeguard the economic generative capacity of cities. Depoliticizing in nature, it suggests that urgent action is needed to address the climate crisis, that the city is the logical scale for climate action, and that new financial mechanisms are needed to boost investment in the type of costly climate projects that are necessary for a 'resilient' future (Long \& Rice, 2019).

The widespread adoption of that narrative has allowed it to be proliferated quickly through multiple scales of climate governance, with new models, methods and experimentation answering the call (Bulkeley \& Castán Broto, 2013; Castán Broto, 2017; Montero, 2020). However, the reality of delivering sufficient capital to fund major climate projects has remained a herculean task (Bigger \& Webber, 2020). Indeed, the amount of money needed for effective climate action is staggering. Estimates range from $\$ 1,6$ trillion per year to $\$ 3,8$ trillion per year between 2016 and 2050 just to meet low-carbon energy transition goals (Clark et al., 2019), and as much as \$90 trillion overall between 2015 and 2030 to meet the needs for climate resilient infrastructure (Global Commission on Economy and Climate, 2016). That outlook has worsened since 2020, as widespread social unrest and economic uncertainty around the Covid-19 epidemic has exposed structural vulnerabilities in emergency response, public health systems, and local economies (Flavelle, 2020; Salas, Shultz, \& Solomon, 2020). Furthermore, these challenges are unfolding against the largest potential debt crisis in decades, which threatens developing and middle-income countries with over $\$ 130$ billion in debt service payments (Stiglitz \& Rashid, 2020).

With this in mind, it is easy to see why the private sector is being so heavily courted. The amount of unspent private capital in the global North has grown to record levels (Karsh \& Robertson, 2020), resulting in an overabundance of idle Northern capital in search of investable projects (Bigger \& Webber, 2020). Aside from renewable energy and sustainable transportation projects, however, private firms have had minimal interest in investing in potentially risky, low-return projects. This is especially true for large-scale, capitalintensive infrastructure projects, which were traditionally financed by the public sector or multilateral development aid. Yet, those conventional sources may be drying up. The Covid-19 epidemic is testing alreadystrained government budgets, and the financial situation of multilateral aid organizations has been troubled by discontinuity and a reduction in member funding. In response, multilateral and development agencies are now casting themselves as knowledge brokers and interlocutors that serve to connect private capital with 'bankable' climate projects. As the executive vice president of the International Finance Corporation noted in a 2016 report:

There has never been a better time to invest in climate solutions.....International Finance Corporation stands ready to support the private sector in its quest to invest more in industries that will improve the climate and yield healthy returns on investment....Working together, we can reduce climate's impact on the poor, while creating new 
markets for the private sector. (International Finance Corporation, 2016, p. v)

Despite an abundance of available capital, private investors were relatively slow to engage in climate finance, particularly in adaptation projects like the construction of defensive sea walls, climate-proofing utility infrastructures, enhancing the resiliency of water and agriculture systems, and improving emergency response systems. With little support from the private sector, some of the most significant infrastructure needs remain unfinanced; while increasing, adaptation projects accounted for only $12 \%$ of all climate finance commitments at the end of 2019 (International Development Finance Club, 2019).

As a result, engaging the private sector has taken priority in the promotional documents and public actions of the World Bank, United Nations, OECD, Global Commission on the Economy and Environment, Rockefeller Foundation, World Resource Institute, Asian Development Bank, and others. Collectively, these organizations have pitched climate finance as an investment opportunity with reliable returns and-following the lead of the World Bank-have established themselves as necessary arbiters and intermediaries of this global program. As (then) president of the World Bank President Jim Yong Kim noted in 2016: "It is not just about trying to persuade donors and financiers to put up more money, although we are definitely trying to do that, but it is also about creating the environment that crowds in a lot more financing" (United Nations, 2016).

In response, organizations have focused their attention on identifying new markets and projects (International Finance Corporation, 2016), making existing markets and projects more investor-friendly (Bigger \& Webber, 2020), and creating political and financial risk assurance to encourage private lenders to invest. For instance, an International Finance Corporation (2016, p. v) report on climate investment opportunities states their intention of "providing information for investors, banks and companies about the most attractive climate investment opportunities, while offering governments a set of best practice policies and measures that have been proven to attract private investment." A report from the Climate Policy Initiative (Buchner et al., 2019) encourages governments to "identify the business models that can best enable private investment at scale," and the Asian Development Bank notes the importance of using financial policies to make climate investment more attractive: "The role of fiscal policy in increasing the rate of return for green projects and thereby elevating the private sector's share in these projects is crucial" (Sachs, Woo, Yoshino, \& Taghizadeh-Hesary, 2019, p. 6). The United Nations Green Climate Fund has offered "a wide range of financial products including grants, concessional loans, subordinated debt, equity, and guarantees" in order to adapt and "overcome market barriers for private finance" (Ephraim, 2019). Yet, while a host of financial mechanisms and policies have been proposed to engage the private sector, nothing has been as successful as the growth of green bonds.

Traditional sources of funding such as grants, forgivable loans, and other mechanisms have remained a part of aid and finance packages from donor countries and philanthropic organizations, but in recent years, the growth of green bonds has emerged as the most important form of climate finance in terms of overall share of capital investment in climate-focused projects (Jones, Baker, Huet, Murphy, \& Lewis, 2020). Relatively insignificant prior to 2010, green bond issuance rose to $\$ 323$ billion by the end of 2019, eclipsing earlier projections (Kuchtyak \& Davison, 2020). Even as the Covid-19 pandemic threatened to slow down the green bond market in 2020, the EU commission announced that approximately $30 \%$ of the $€ 750$ billion Next Generation EU recovery plan will take the form of green bonds, ensuring their continued significance in climate finance (Khan, 2020).

Like conventional 'vanilla' bonds, green bonds are instruments that allow borrowing organizations and institutions access to capital while providing investors with a relatively risk averse, low return investment option. Paraphrasing Jones et al. (2020, p. 50): On the issuer side, green bonds typically allow access to large amounts of capital that can be acquired more cheaply than through direct bank loans, and as such, are an especially attractive option for expensive projects like major infrastructure initiatives focused on adaptation. This makes them an ideal fit for development agencies whose recent focus-as previously mentioned-has been to unlock private capital and funnel investment to priority climate projects through private-public partnerships.

As scholars have noted, however, the rapid growth and popularization of green bonds is not without its faults (Bigger \& Millington, 2020; Clark, Reed, \& Sunderland, 2018; Jones et al., 2020). Indeed, the transformation of climate finance has introduced numerous concerns about ambiguity in climate finance regulation (Hall, 2017), the de-politicizing effects of a mainstreamed message of adaptation (Scoville-Simonds, Jamali, \& Hufty, 2020), the denial or lack of evaluation of social dimensions of projects (García-Lamarca \& Ullström, 2020), and the likelihood of reviving a new iteration of structural adjustment policy reminiscent of the Washington Consensus (Bigger \& Webber, 2020).

Green bonds provide a model to monetize the climate crisis, but this model works for other crises as well. The recent introduction of 'sustainable bonds'-bonds that are applied to finance a combination of green and social projects-has allowed the green bond model to be reformulated for investors seeking to add a social dimension to their portfolios. Writing in Environmental Finance, a DZ Bank representative recently declared the 2020s "the decade of sustainable bonds" (Pratsch, 2020). After the obligatory tone of urgency in his framing of crisis: "Time is running out. The point of no return is approaching," Pratsch announced a "green goes rainbow" trend in 
development finance. The ambiguous regulatory structure of green bonds applies similarly to sustainable bonds, and most recently 'Covid-19 bonds,' the latter of which have no clear definition or regulation, but still managed to raise $\$ 150$ billion between March and June of 2020 (Hirtenstein, 2020).

This is no coincidence. Throughout the Covid-19 crisis, multilateral agencies have actively promoted the green bond model as a way to further engage the private sector for other crises. In a recent report, the International Finance Corporation suggested that a successful response to the Covid-19 crisis will:

Mirror the approach that we at the International Finance Corporation are using to tackle the climate crisis: that investors, businesses and financial institutions must lead the way....It's a business plan that's not only positive for the environment, but also good for people and profitability. (Klein, 2020, p. 1)

As the report's title suggests, private sector influence is an apparent 'sustainable' solution in an era of crisis: "When it comes to sustainable finance in the COVID era, let the private sector lead the way" (p. 1).

It is important to note that the monetization of crisis has not happened in a vacuum. A complex assemblage of agencies, institutions, and networks is involved in the administration of new finance mechanisms, and many of these actors have a history of advancing specific political and economic agendas. The following section addresses this issue before advocating for the decolonization of climate finance and climate governance.

\section{Orchestrating Crisis: Old and New Actors in Urban Climate Governance}

Numerous scholars have written about the evolution of urban climate governance (see for instance, Anguelovski \& Carmin, 2011; Bulkeley et al., 2012; Gordon \& Johnson, 2017). Their work is important context for this section, which focuses on the recent surge of intermediate actors in the system. That surge can largely be attributed to three reasons: the need to secure funding in the wake of the 2007-2009 financial crisis, the commitments (however loosely enforced) introduced in the 2015 Paris Climate Agreement, and lastly, the aforementioned push to engage the private sector in climate finance. The rapid growth of actors in urban climate governance has resulted in a complex assemblage of organizations, institutions, and agencies. Scholars have referred to the "entangled web...of the global urban resilience complex" (Webber et al., 2020, p. 5), the growing "dominance of intermediaries" in climate finance (Chaudhury, 2020, p. 1), and the "Cambrian explosion of organizations, norms, contributions, commitments, and other institutions" involved in climate governance (Abbott, 2017). While many of the most influential actors (particularly multilateral agencies like the World Bank, or philan- thropic organizations like the Rockefeller Foundation) pre-date the 21st century rise in climate-oriented organizations, most have appeared in the past decade or so.

Because of their number and novelty, it has remained difficult-if not impossible-to keep track of new programs, intermediaries, and transnational investment relationships. The scholarship on intermediary actors in climate governance (see, for instance, Bäckstrand, Zelli, \& Schleifer, 2018; Chaudhury, 2020; Gordon \& Johnson, 2017) suggests the necessity of experts and institutions for the following: (1) To identify 'bankable' climate projects and connect funding sources to local municipalities; (2) to provide knowledge and expertise to municipalities with minimal experience in the types of climate adaptation projects promoted by influential organizations; (3) to assign credit ratings to municipalities and augment the capacity of cities to secure higher credit ratings so as to gain access to pools of funding; and (4) to administer, assess, and create accountability mechanisms for streams of finance.

As mentioned previously, multilateral organizations like the United Nations, World Bank, and IMF have recast themselves as knowledge brokers, problem solvers, and necessary 'middlemen' in financing climate action (Chaudhury, 2020; Scoville-Simonds et al., 2020). Partnering with corporate entities, influential philanthropic organizations, and other private actors has been key to their stated mission of unlocking private capital. Beyond traditional actors, a host of transmunicipal networks (such as C40 Cities Climate Leadership Group, the Covenant of Mayors, Cities for Climate Protection, and others) promote cities as pragmatic leaders capable of enacting policies and disseminating information and expertise to their municipal peers (Bansard, Pattberg, \& Widerberg, 2017). Additionally, a host of institutional think-tanks and non-profits like Earth Institute Resilient Cities, World Resource Institute, the Resilient Cities Catalyst, and others serve as consultants, project designers, brokers, and analysts. More recently, a host of Project Preparation Facilities have emerged specifically to serve as intermediaries between new sources of capital and state and local actors in order to develop bankable, investment-ready infrastructure projects (Perera, Uzsoki, \& Rana, 2017). Project Preparation Facilities are portrayed as particularly important for climatevulnerable cities in developing countries, where connecting investors with bankable projects, administering those projects, and implementing those projects "requires skills and expertise that are not immediately available within municipal administrations" (Gorelick \& Walmsley, 2020, p. 120).

The above list is abbreviated, and only begins to list a few of the many actors involved. As scholars have suggested, the proliferation of such organizations represents the emergence of a novel, ambiguous, and complex landscape of urban climate governance (Chan, Falkner, Goldberg, \& Van Asselt, 2018; Chaudhury, 2020; Gordon \& Johnson, 2017). Numerous scholars have 
created frameworks that attempt to distinguish among different modes of 'climate governance orchestration' and their democratic legitimacy, efficacy, and underlying politics and power structures (see for instance, Abbott, 2017; Bäckstrand et al., 2018; Gordon \& Johnson, 2017; Hölscher \& Frantzeskaki, 2020; Kuyper, Linnér, \& Schroeder, 2018). Yet each of these studies struggles to portray a clear and comprehensive picture of the architecture of this orchestration, and furthermore, many of these works express concerns about equity, justice, and democratic legitimacy in climate governance.

However, while a clear picture of this system remains elusive, certain commonalities point to underlying motivations and potential outcomes, all of which are related. First, while most of these organizations are transnational in their scope, nearly all are headquartered in the global North (Bansard et al., 2017; Bulkeley et al., 2012; Chan et al., 2018), and as such, reflect a notably western set of strategies and ideologies. Second, the messaging found in their mission statements and guidelines largely reflects the priorities and practices of the most influential development multilaterals, notably the United Nations and the World Bank. This includes, for instance, the use of specific metrics, rationales, administrative structures, feedback tools, and the employment of an overall language of inclusion and local participation; it is worth noting again that the legitimacy of each of these is highly questionable (Bäckstrand et al., 2018; Kuyper et al., 2018). Lastly, the vast majority of these actors have begun to repeat the resilience-amidst-crisis narrative of climate urbanism, which assumes that urgent, largescale action is needed, that urban infrastructure and city citizens should be the focal point of these projects, and that financing these projects is dependent on providing access to investment capital (in this case, much of that capital originates in the private sector). This last part is key, because deference to private interests and a few notable philanthropic actors has already allowed a notable degree of elitist influence in development agendas (Graham, 2017). In short, the increasing complexity and lack of accountability in the administration of climate finance not only forces recipients to acquire the resources needed to navigate this system, it provides enormous flexibility to the most powerful and influential actors to orchestrate a system of debt finance that meets their own priorities.

The title of this section-orchestrating crisis-is intended to strike a troubling chord. Read literally, it implies that the current system of urban climate governance plays a role in exacerbating, rather than mitigating, the climate crisis. This article suggests that both are partially true and that this contradiction is important to understanding the intractable nature of the climate crisis. Indeed, the root causes of anthropogenic climate change are political and systematic. This means that while modes of governance embedded within those structures are capable of mitigating the elemental causes of climate change (i.e., greenhouse gases), they often serve to entrench the historical and systematic causes of the climate crisis (i.e., capitalism, patriarchy, and colonialism; Rice, Long, \& Levenda, 2021). The next section addresses this, and discusses the ways that the climate crisis is framed as a depoliticized issue solvable by a mode of urban climate governance that reproduces the very systems that create crisis, profit from crisis, and entrench power through crisis.

\section{Conclusion: Profit, Power, and the Coloniality of the Climate Crisis}

Interrogating the strategic shift promoted by development organizations and their private counterparts reveals a great deal about the complexity of the climate crisis-an exercise that is helpful in locating strategies for decolonizing and democratizing climate action. This section acknowledges some of the contradictions in the rhetoric of climate development before concluding with a discussion of pathways forward for action and intervention.

First, it is imperative to acknowledge the urgency of the climate crisis. Climate change is indeed an urgent threat and immediate action is necessary. But framing the climate crisis as such allows room to expedite unjust policies, and this rhetoric should be the first area that policymakers and activists examine for potential abuse. This is particularly true when urgency is used to justify austere policies that support the most powerful actors, overshadow the injustices that will be heightened by those policies, and obfuscate the political and historical contexts that created these crises in the first place (Long \& Rice, 2020). As Whyte (in press) notes, this is a conscious tactic that allows policy discussions to completely ignore the abuses of (continued) colonial power.

Second, cities are indeed logical spaces to prioritize climate action, but this focus is being implemented in a myopic manner. The framing of urban action as a pragmatic way to curb emissions and protect the majority of the world's population introduces multiple caveats. The most obvious of these is that it suggests a false dichotomy between rural and urban, thereby ignoring the metabolic and political interrelationships that permeate our climate-changed world. Put another way, issues such as forced migration, geophysical transformation (e.g., rising sea levels, erosion, flooding, etc.), the politics of anticipatory ruination (Paprocki, 2019) and the political economy of climate retreat (Scott \& Lennon, 2020) all challenge what we mean by 'urban.'

Third, while engaging private capital is an important component of climate funding, hopes that the private sector will emerge as the responsible leader in just, equitable, and sustainable development are misplaced. As the private sector's role in climate finance has increased, so has critical scholarship that expresses concern about equity issues associated with a for-profit model, their increasing influence in development agendas, their lack of meaningful engagement with target 
communities, their tepid progress on adaption projects, the lack of credible oversight and regulation, and their overdependence on credit ratings, risk assurances, and market stability (Bigger \& Millington, 2020; Bigger \& Webber, 2020; Clark et al., 2018; Graham, 2017; Hall, 2017; Jones et al., 2020; Kuyper et al., 2018; Pauw, 2015; Walenta, 2018). Furthermore, it is becoming clear that the emergence of green and sustainable bond markets as funding mechanisms-orchestrated by institutions like the World Bank-embody what Bigger and Webber (2020) refer to as 'Green Structural Adjustment.' As this article has argued, aspects of the emerging climate finance system potentially represent a new mode of colonial control through debt bondage adapted for the neoliberal era.

Ultimately, the funding strategies that accompany this resilience-amidst-crisis narrative are not intended to tackle the complexity of the climate crisis or assist those most vulnerable. Instead, they are promoted to increase investment potential and ensure profit, while advancing a subjective vision of climate action disguised as global altruism. Confronting this problem requires twofold action. While scholars and educators are working to unmask and abolish the structural power dynamics in the climate development sector, activists and community leaders are working to promote development models and systems of governance that are inclusive, distributive, and participatory.

In a practical sense, this requires a significant disciplining of the financial sector, an empowering of the public sector, a rethinking of budget priorities toward resource redistribution, and a meaningful commitment to transparent democratic engagement. For many of the influential actors in climate development, this is an uphill task. Addressing one of those measures would be viewed as difficult, addressing more than one would be perceived as radical, addressing all of them would be considered revolutionary. At the same time, frameworks for critical intervention already exist (for example: Castán Broto et al., 2020; Pellow, 2018; Pulido \& De Lara, 2018; Ranganathan \& Bratman, 2019; Whyte, 2017), as do approaches that blend critical theory and practical policy approaches (for example, recent works on the Green New Deal and de-growth economics: Arnoff, Battistoni, Cohen, \& Riofrancos, 2019; Goh, 2020; Patel \& Goodman, 2020; Rodríguez-Labajos et al., 2019). Additionally, there are myriad calls for increased regulation of the green bond market and climate finance more broadly, many of which have already been cited earlier in this article. Not all of these approaches are radical, and some include more reasonable strategies to engaging the private sector (Clark et al., 2018) and even include calls for reform from within multilateral agencies themselves (e.g., Fullenkamp \& Rochon, 2017).

Admittedly, despite the existence of both practical and conceptual roadmaps for intervention, the many historical structures of injustice remain the largest roadblock. The economic imaginaries, inclusions, and exclu- sions created by the financial sector are deeply embedded in a system of colonial supremacy and racial capitalism that will not be dismantled overnight (John, 2018). Likewise, empowering the public sector must recognize that the state is itself a historical colonial apparatus built upon Indigenous theft and violence. However, the enforcement capabilities of the nation-state, acting on behalf of the public, hold the sovereign power to discipline and regulate financial institutions, and commit to transparent, democratic solutions. Ultimately, any solution to the climate crisis must prioritize a postcolonial perspective that (1) recognizes the legitimacy of a multitude of climate actions, (2) empowers local knowledge and decision-making capacity, and (3) makes social justice concerns paramount (Robin \& Castán Broto, 2020). As Sultana (2019, p. 42) notes, this is an ongoing struggle that requires collective action:

Decolonizing development is a collective project, not an individual one, nor one that has a timeframe or prefigured set of goals. It requires difficult questions be asked and possibilities envisioned collectively in order to pursue equitable and emancipatory transformations for planetary justice. Decolonizing has to be a collaborative journey and a collective struggle of committed individuals.

The next two decades will determine if the design, funding, and implementation of climate projects and policies emerge in a just, democratic, and equitable manner, or if they materialize in a political economic landscape of profit, polarization, and segregation. This necessitates a collective, rather than individual, political projectone that subverts systems that profit from crisis, rejects a mentality of resilience-amidst-crisis, and empowers communities toward collaborative, democratic, and equitable climate action.

\section{Acknowledgments}

I would like to thank the Academic Editors and anonymous reviewers for their constructive insight that greatly improved this manuscript.

\section{Conflict of Interests}

The author declares no conflict of interests.

\section{References}

Abbott, K. W. (2017). Orchestration: Strategic ordering in polycentric climate governance. SSRN. https://doi. org/10.13140/RG.2.2.10435.60962

Angelo, H., \& Wachsmuth, D. (2020). Why does everyone think cities can save the planet? Urban Studies, 57(11), 2201-2221.

Anguelovski, I., \& Carmin, J. (2011). Something borrowed, everything new: Innovation and institutional- 
ization in urban climate governance. Current opinion in environmental sustainability, 3(3), 169-175.

Arnoff, K., Battistoni, A., Cohen, D. A., \& Riofrancos, T. (2019). A planet to win: Why we need a Green New Deal. New York, NY: Verso Books.

Azmanova, A. (2020). Anti-capital for the XXIst century (on the metacrisis of capitalism and the prospects for radical politics). Philosophy \& Social Criticism, 46(5), 601-612.

Bäckstrand, K., Zelli, F., \& Schleifer, P. (2018). Legitimacy and accountability in polycentric climate governance. Governing Climate Change: Polycentricity in Action, 338-356. https://doi.org/10.1017/9781108284646. 020

Bansard, J. S., Pattberg, P. H., \& Widerberg, O. (2017). Cities to the rescue? Assessing the performance of transnational municipal networks in global climate governance. International Environmental Agreements: Politics, Law and Economics, 17(2), 229-246.

Bigger, P., \& Millington, N. (2020). Getting soaked? Climate crisis, adaptation finance, and racialized austerity. Environment and Planning E: Nature and Space, 3(3), 601-623.

Bigger, P., \& Webber, S. (2020). Green structural adjustment in the World Bank's resilient city. Annals of the American Association of Geographers, 111(1), 1-16. https://doi.org/10.1080/24694452.2020.1749023

Boin, A., Hart, P., \& McConnell, A. (2009). Crisis exploitation: Political and policy impacts of framing contests. Journal of European Public Policy, 16(1), 81-106.

Brown, J., Bird, N., \& Schalatek, L. (2010). Climate finance additionality: Emerging definitions and their implications. Climate Finance Policy Brief, 2, 1-11.

Buchner, B., Clark, A., Falconer, A., Macquarie, R., Meattle, C., Tolentino, R., \& Wetherbee, C. (2019). Global landscape of climate finance 2019. Climate Policy Initiative. Retrieved from https://www. climatepolicyinitiative.org/publication/globallandscape-of-climate-finance-2019

Bulkeley, H., Andonova, L., Bäckstrand, K., Betsill, M., Compagnon, D., Duffy, R., . . Milledge, T. (2012). Governing climate change transnationally: Assessing the evidence from a database of sixty initiatives. Environment and Planning C: Government and Policy, 30(4), 591-612.

Bulkeley, H., \& Castán Broto, V. (2013). Government by experiment? Global cities and the governing of climate change. Transactions of the Institute of British geographers, 38(3), 361-375.

Bumpus, A. G., \& Liverman, D. M. (2011). Carbon colonialism? Offsets, greenhouse gas reductions, and sustainable development. In R. Peet, P. Robbins, \& M. Watts (Eds.), Global political ecology (pp. 230-224). London: Routledge.

Castán Broto, V. (2017). Urban governance and the politics of climate change. World Development, 93, 1-15.

Castán Broto, V., Robin, E., \& While, A. (2020). Climate urbanism: Towards a critical research agenda. London: Palgrave Macmillan.

Castree, N. (2010). Crisis, continuity and change: Neoliberalism, the left and the future of capitalism. Antipode, 41, 185-213.

Chan, S., Falkner, R., Goldberg, M., \& Van Asselt, H. (2018). Effective and geographically balanced? An output-based assessment of non-state climate actions. Climate Policy, 18(1), 24-35.

Chaudhury, A. (2020). Role of intermediaries in shaping climate finance in developing countries: Lessons from the Green Climate Fund. Sustainability, 12(14). https://doi.org/10.3390/su12145507

Clark, A., Falconer, A., Buchner, B., Meattle, C., Weatherbee, C., Macquarie, R., \& Tolentino, R. (2019). The global landscape of climate finance. Climate Policy Initiative. Retrieved from https://cpiredesign. wpengine.com/publication/global-landscape-ofclimate-finance-2019

Clark, R., Reed, J., \& Sunderland, T. (2018). Bridging funding gaps for climate and sustainable development: Pitfalls, progress and potential of private finance. Land Use Policy, 71, 335-346.

Coaffee, J. (2009). Terrorism, risk and the global city: Towards urban resilience. Farnham: Ashgate Publishing Limited.

Donner, S. D., Kandlikar, M., \& Webber, S. (2016). Measuring and tracking the flow of climate change adaptation aid to the developing world. Environmental Research Letters, 11(5). https://doi.org/10.1088/ 1748-9326/11/5/054006

Ephraim, J. (2019, October 16). Climate change financing: The breakthrough for the Caribbean's sustainable energy transition? [Press release]. Retrieved from https://pressroom.oecs.org/climate-changefinancing-the-breakthrough-for-the-caribbeanssustainable-energy-transition

Evans, B., \& Reid, J. (2014). Resilient life: The art of living dangerously. New York, NY: John Wiley \& Sons.

Falconer, A., \& Stadelmann, M. (2014). What is climate finance? Definitions to improve tracking and scale up climate finance. Venice: Climate Policy Initiative. Retrieved from https://arca.unive.it/retrieve/ handle/10278/43732/31800/CPI\%202014\%20Briefon-Climate-Finance-Definitions.pdf

Flavelle, C. (2020, April 23). Here's how coronavirus could raise cities' risk for climate disasters. The New York Times. Retrieved from https://www.nytimes. com/2020/04/23/climate/coronavirus-citiesinfrastructure-money.html

Fletcher, R. (2012). Capitalizing on chaos: Climate change and disaster capitalism. Ephemera: Theory \& Politics in Organization, 12, 97-112.

Fullenkamp, C., \& Rochon, C. (2017). Reconsidering bank capital regulation: A new combination of rules, regulators, and market discipline. Journal of Economic Policy Reform, 20(4), 343-359.

García-Lamarca, M., \& Ullström, S. (2020). “Everyone 
wants this market to grow": The affective postpolitics of municipal green bonds. Environment and Planning E: Nature and Space. https://doi.org/ $10.1177 / 2514848620973708$

Global Commission on Economy and Climate. (2016). The sustainable infrastructure imperative: Financing for better growth and development. Global Commission on Economy and Climate. Retrieved from http:// newclimateeconomy.report/2016/wp-content/ uploads/sites/4/2014/08/NCE_2016Report.pdf

Goh, K. (2020). Planning the Green New Deal: Climate justice and the politics of sites and scales. Journal of the American Planning Association, 86(2), 188-195.

Gordon, D. J., \& Johnson, C. A. (2017). The orchestration of global urban climate governance: Conducting power in the post-Paris climate regime. Environmental Politics, 26(4), 694-714.

Gorelick, J., \& Walmsley, N. (2020). The greening of municipal infrastructure investments: Technical assistance, instruments, and city champions. Green Finance, 2(2), 114-134.

Graham, E. R. (2017). Follow the money: How trends in financing are changing governance at international organizations. Global Policy, 8, 15-25.

Hall, N. (2017). What is adaptation to climate change? Epistemic ambiguity in the climate finance system. International Environmental Agreements: Politics, Law and Economics, 17(1), 37-53.

Harvey, H. (2010). The enigma of capital and the crises of capitalism. London: Oxford University Press.

Hirtenstein, A. (2020, June 3). Investors channel over $\$ 150$ billion into coronavirus bonds. The Wall Street Journal. Retrieved from https://www.wsj.com/ articles/investors-channel-over-150-billion-intocoronavirus-bonds-11591178004

Hölscher, K., \& Frantzeskaki, N. (2020). Navigating transformations under climate change in cities: Features and lock-ins of urban climate governance. In $\mathrm{K}$. Hölscher \& N. Frantzeskaki (Eds.), Transformative climate governance (pp. 113-162). Cham: Palgrave Macmillan.

Intergovernmental Panel on Climate Change. (2012). Summary for policymakers. In V. Barros, T. F. Stocker, D. Qin, D. J. Dokken, K. L. Ebi, M. D. Mastrandrea, . . . P. M. Midgley (Eds.), Managing the risks of extreme events and disasters to advance climate change adaptation (pp. 1-19). Cambridge: Cambridge University Press.

International Development Finance Club. (2019). Green finance mapping report. International Development Finance Club. Retrieved from https:// www.idfc.org/wp-content/uploads/2019/12/idfc_ report_final-2.pdf

International Finance Corporation. (2016). Climate investment opportunities in emerging markets: An International Finance Corporation analysis. New York, NY: World Bank Group.

John, T. J. (2018). Settler colonialism and finan- cial exclusion of banks in the English Caribbean. E-International Relations. Retrieved from https:// www.e-ir.info/pdf/76041

Jones, R., Baker, T., Huet, K., Murphy, L., \& Lewis, N. (2020). Treating ecological deficit with debt: The practical and political concerns with green bonds. Geoforum, 114, 49-58.

Karaagac, E. A. (2020). The financialization of everyday life: Caring for debts. Geography Compass. https:// doi.org/10.1111/gec3.12541

Karsh, M., \& Robertson, B. (2020, January 2). Private equity is starting 2020 with more cash than ever before. Bloomberg. Retrieved from https://www. bloomberg.com/news/articles/2020-01-02/privateequity-is-starting-2020-with-more-cash-than-everbefore

Khan, M. (2020, September 13). EU explores green bonds as part of $€ 750$ bn borrowing spree. Financial Times. Retrieved from https://www.ft.com/content/ 7a893f6d-08c9-426c-8f19-aa19d434b018

Klein, A. (2020). When it comes to sustainable finance in the COVID era, let the private sector lead the way. World Bank Blogs. Retrieved from https://blogs. worldbank.org/climatechange/when-it-comessustainable-finance-covid-era-let-private-sectorlead-way

Klein, N. (2007). Disaster capitalism. Harper's Magazine, $315,47-58$.

Kuchtyak, M., \& Davison, A. (2020). Green, social and sustainability bond issuance to jump 24\% in 2020 to $\$ 400$ billion. Moody's Investor Service. Retrieved from https://www.moodys.com/research/MoodysGreen-social-and-sustainability-bond-issuance-tojump-24-V-PBC_1212910

Kuyper, J. W., Linnér, B. O., \& Schroeder, H. (2018). Non-state actors in hybrid global climate governance: Justice, legitimacy, and effectiveness in a post-Paris era. Wiley Interdisciplinary Reviews: Climate Change, 9(1). https://doi.org/10.1002/wcc.497

Long, J., \& Rice, J. L. (2019). From sustainable urbanism to climate urbanism. Urban Studies, 56(5), 992-1008.

Long, J., \& Rice, J. L. (2020). Climate urbanism: Crisis, capitalism, and intervention. Urban Geography. https:// doi.org/10.1080/02723638.2020.1841470

McDonnell, S. (2020). Other dark sides of resilience: Politics and power in community-based efforts to strengthen resilience. Anthropological Forum, 30(1/2), 55-72.

Meerow, S., \& Stults, M. (2016). Comparing conceptualizations of urban climate resilience in theory and practice. Sustainability, 8(7), 701.

Montero, S. (2020). Leveraging Bogotá: Sustainable development, global philanthropy and the rise of urban solutionism. Urban Studies, 57(11), 2263-2281.

New Climate Economy. (2018). Unlocking the inclusive growth story of the 21st century. New Climate Economy. Retrieved from https://newclimateeconomy. report/2018 
Octavianti, O., \& Charles, K. (2018). Disaster capitalism? Examining the politicisation of land subsidence crisis in pushing Jakarta's seawall megaproject. Water Alternatives, 11(2), 394-420.

Paprocki, K. (2019). All that is solid melts into the bay: Anticipatory ruination and climate change adaptation. Antipode, 51(1), 295-315.

Patel, R., \& Goodman, J. (2020). The long new deal. The Journal of Peasant Studies, 47(3), 431-463.

Pauw, W. P. (2015). Not a panacea: Private-sector engagement in adaptation and adaptation finance in developing countries. Climate Policy, 15(5), 583-603.

Pellow, D. N. (2018). What is critical environmental justice? Cambridge: Polity Press.

Perera, O., Uzsoki, D., \& Rana, F. (2017). Project preparation facility: Enabling local governments access to private finance. Winnipeg: International Institute for Sustainability. Retrieved from https://www.iisd.org/ sites/default/files/publications/project-preparationfacility-government-access-private-finance.pdf

Perry, K. K. (2020). The new 'bond-age,' climate crisis and the case for climate reparations: Unpicking old/new colonialities of finance for development within the SDGs. SocArXiv. https://doi.org/10.31235/ osf.io/h9s2z

Pratsch, M. (2020). The 2020s: The decade of sustainable bonds. Environmental Finance. Retrieved from https://www.environmental-finance.com/content/ the-green-bond-hub/the-2020s-the-decade-ofsustainable-bonds.html

Pulido, L., \& De Lara, J. (2018). Reimagining 'justice' in environmental justice: Radical ecologies, decolonial thought, and the Black Radical Tradition. Environment and Planning E: Nature and Space, 1(1/2), 76-98.

Pyles, L., Svistova, J., \& Ahn, S. (2017). Securitization, racial cleansing, and disaster capitalism: Neoliberal disaster governance in the US Gulf Coast and Haiti. Critical Social Policy, 37(4), 582-603.

Quijano, A. (2000). Coloniality of power and Eurocentrism in Latin America. International Sociology, 15(2), 215-232.

Ranganathan, M., \& Bratman, E. (2019). From urban resilience to abolitionist climate justice in Washington, DC. Antipode. https://doi.org/10.1111/anti. 12555

Reid, J. (2019). "We the resilient": Colonizing indigeneity in the era of trump. Resilience, 7(3), 255-270.

Rice, J., Long, J., \& Levenda, A. (2021). Against climate apartheid: Confronting the persistent legacies of expendability for climate justice. Environment and Planning E: Nature and Space. Advance online publication. https://doi.org/10.1177/2514848621999286

Roberts, J. T., \& Weikmans, R. (2017). Postface: Fragmentation, failing trust and enduring tensions over what counts as climate finance. International Environmental Agreements: Politics, Law and Economics, 17(1), 129-137.
Robin, E., \& Broto, V. C. (2020). Towards a postcolonial perspective on climate urbanism. International Journal of Urban and Regional Research. https://doi.org/ 10.1111/1468-2427.12981

Rodríguez-Labajos, B., Yánez, I., Bond, P., Greyl, L., Munguti, S., Ojo, G. U., \& Overbeek, W. (2019). Not so natural an alliance? Degrowth and environmental justice movements in the Global South. Ecological Economics, 157, 175-184.

Rosenzweig, C., Solecki, W., Hammer, S. A., \& Mehrotra, S. (2010). Cities lead the way in climate-change action. Nature, 467(7318), 909-911.

Sachs, J. D., Woo, W. T., Yoshino, N., \& TaghizadehHesary, F. (2019). Why is green finance important? SSRN. http://dx.doi.org/10.2139/ssrn.3327149

Salas, R. N., Shultz, J. M., \& Solomon, C. G. (2020). The climate crisis and COVID-19: A major threat to the pandemic response. New England Journal of Medicine, 383(11). https://doi.org/10.1056/NEJMp2022011

Schuller, M., \& Maldonado, J. K. (2016). Disaster capitalism. Annals of Anthropological Practice, 40(1), 61-72.

Scott, M., \& Lennon, M. (2020). Climate disruption and planning: Resistance or retreat? Planning Theory \& Practice, 21(1), 125-154.

Scoville-Simonds, M., Jamali, H., \& Hufty, M. (2020). The hazards of mainstreaming: Climate change adaptation politics in three dimensions. World Development, 125. https://doi.org/10.1016/j.worlddev. 2019.104683

Seitz, K., \& Martens, J. (2017). Philanthrolateralism: Private funding and corporate influence in the United Nations. Global Policy, 8, 46-50.

Serrano-García, I. (2020). Resilience, coloniality, and sovereign acts: The role of community activism. American Journal of Community Psychology, 65(1/2), 3-12.

Soederberg, S. (2013). Universalising financial inclusion and the securitisation of development. Third World Quarterly, 34(4), 593-612.

Stiglitz, J., \& Rashid, H. (2020). Averting catastrophic debt crises in developing countries (CEPR Insight No. 14). Washington, DC: Center for Economic Policy Research.

Sultana, F. (2019). Decolonizing development education and the pursuit of social justice. Human Geography, 12(3), 31-46.

United Nations. (2016). UN Chief urges rapid scale-up in climate funding to address climate change. United Nations News. Retrieved from https://news.un.org/ en/story/2016/11/545502-marrakech-un-chiefurges-rapid-scale-funding-address-climate-change

Walenta, J. (2018). The limits to private-sector climate change action: The geographies of corporate climate governance. Economic Geography, 94(5), 461-484.

Webber, S., Leitner, H., \& Sheppard, E. (2020). Wheeling out urban resilience: Philanthrocapitalism, marketization, and local practice. Annals of the American 
Association of Geographers, 111(2), 1-21.

While, A., Jonas, A. E., \& Gibbs, D. (2010). From sustainable development to carbon control: Eco-state restructuring and the politics of urban and regional development. Transactions of the Institute of British Geographers, 35(1), 76-93.

Whyte, K. (2017). Indigenous climate change studies:
Indigenizing futures, decolonizing the Anthropocene. English Language Notes, 55(1), 153-162.

Whyte, K. (in press). Against crisis epistemology. In B. Hokowhitu, A. Moreton-Robinson, L. Tuhiwai-Smith, C. Andersen, \& S. Larkin (Eds.), Routledge handbook of critical indigenous studies. New York, NY: Routledge.

\section{About the Author}

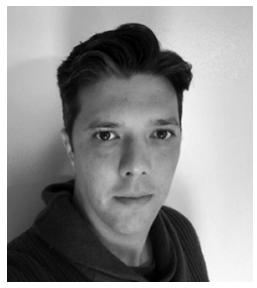

Joshua Long is an interdisciplinary Human Geographer with research interests in climate justice, critical sustainability, urban studies, and place-based studies. Long serves as Chair of the Environmental Studies Program at Southwestern University in Georgetown, Texas. 